\title{
Hepatitis A virus epidemiology in Turkey as universal childhood vaccination begins: seroprevalence and endemicity by region
}

\author{
Tayfur Demiray ${ }^{1}$, Mehmet Köroğlu², Kathryn H. Jacobsen³ ${ }^{2}$ Ahmet Özbek ${ }^{2}$, Hüseyin A. Terzi ${ }^{1}$, \\ Mustafa Altındiş² \\ ${ }^{1}$ Clinical Microbiology Laboratory, Sakarya University Education and Research Hospital, 2 Department of Medical \\ Microbiology, Faculty of Medicine, Sakarya University, Sakarya, Turkey, ${ }^{3}$ Department of Global E Community Health, \\ George Mason University, Fairfax, Virginia, USA. E-mail: maltindis@gmail.com \\ Received: 6th April 2016, Revised: 5th September 2016, Accepted: 17th January 2017
}

SUMMARY: Demiray T, Köroğlu M, Jacobsen KH, Özbek A, Terzi HA, Altındiş M. Hepatitis A virus epidemiology in Turkey as universal childhood vaccination begins: seroprevalence and endemicity by region. Turk J Pediatr 2016; 58: 480-491.

This paper presents the results of a comprehensive examination of current distribution of Hepatitis A virus (HAV) seroprevalence and endemicity in Turkey and the possible links between HAV endemicity and socioeconomic development. We performed a systematic search in online resources published between January 2000 and August 2015. The 22 provinces were able to be assigned a hepatitis A endemicity level based on this systematic review. The incidence rates for symptomatic hepatitis A infection are higher in the eastern part of Turkey than in the western and central region. These differences in socioeconomic indicators by region suggest the likelihood of lower seroprevalence rates in the western parts of the country and higher rates in the eastern region. Turkey's current policy of recommending hepatitis A immunization for all children without contraindications is an appropriate one and is likely to remain the best option for at least the next decade or two.

Key words: Hepatitis A virus, endemicity, seroprevalence, vaccination, socioeconomic development

Hepatitis A virus (HAV) is usually acquired through contact with an infected person or through ingestion of contaminated water or food, and it is one of the major causes of acute viral hepatitis globally ${ }^{1}$. The severity and clinical course of the infection vary according to the age of the patient. When acquired in the early years of the life, HAV infection is often asymptomatic. With advancing age, jaundice and other symptoms usually occur; liver failure and death are possible complications though occur very rarely. The incidence of the disease varies with access to clean drinking water and other indicators of socioeconomic status ${ }^{2,3}$. Places like Turkey that have undergone significant socioeconomic development in recent decades often transition from having a high incidence of asymptomatic infections in young children to seeing a growing number of outbreaks resulting in symptomatic cases in adults ${ }^{1}$. In these countries, universal childhood vaccination is often cost-effective ${ }^{4}$. Turkey added HAV to its routine immunization schedule in 2012. Since this is likely to change the epidemiological profile of the country, it is important to have a baseline understanding of the heterogeneity of profiles across Turkey.

Because HAV is often asymptomatic, most epidemiological studies rely on serological indicators of past infection (anti-HAV IgG) rather than trying to quantify current infection (anti-HAV IgM). IgG antibodies usually persist for life. The percentage of various age groups of individuals who test positive for anti-HAV IgG provides information about both recent and past epidemiological patterns ${ }^{5}$. A high rate of seropositivity among children reveals a high incidence rate during those children's lifetimes. A low rate in children but a high rate in adults usually indicates that the incidence rate has 
decreased during those adults' lifetimes. Plots of age (on the x-axis) and HAV seroprevalence (on the y-axis) at different places and different time points therefore provide useful information about changing endemicity patterns and offer insights about the most appropriate vaccination strategy for a population.

This paper presents the results of a comprehensive examination of current HAV endemicity patterns across Turkey, the differences by region, and the possible connections between socioeconomic indicators and within-country heterogeneity in HAV seroprevalence rates. This information can be considered a baseline evaluation for tracking the future evolution of HAV endemicity in Turkey after the initiation of the routine vaccination program.

\section{Material and Methods}

Systematic literature search. We performed a systematic search in PubMed, Google Scholar, and EBSCOhost in the Turkish and English languages to identify published articles, conference abstracts, and other online resources published after January 2000 and indexed by January 2016. Publications in all languages were eligible for inclusion, but all articles identified during the search were written in English or Turkish. We also examined the reference lists of all eligible articles to search for non-indexed documents that might meet the eligibility criteria. The systematic review was conducted in accordance with the PRISMA guidelines ${ }^{6}$.

Inclusion and exclusion criteria. Two authors independently evaluated all of the reports to determine whether they met the eligibility criteria. To be eligible, an article had to: (1) be conducted in Turkey; (2) report age-specific
anti-HAV IgG seroprevalence rates or combined IgG/IgM results; (3) report the results of data collected in or after the year 2000; (4) include a population reasonably representative of the general population; (5) include at least 100 participants; and (6) present original results rather than reviewing previously published reports. Articles were excluded if they (1) were not conducted in Turkey; (2) reported HAV incidence rather than prevalence; (3) presented data collected prior to the year 2000; (4) focused on a special population likely to have higher risk for exposure to HAV such as healthcare workers, patients with acute or chronic liver disease, and patients with organ transplants, HIV, or other chronic health issues; (5) included fewer than 100 participants; or (6) were a review article, outbreak investigation, environmental study, or examination of vaccination effectiveness. To ensure the completeness of the evaluation, abstracts from conferences were included when no full paper was published about a research study after it was presented.

Vaccination was not introduced into the routine childhood vaccination schedule in Turkey until 2012, so the participants in studies from earlier years can be assumed not to have received a vaccine ${ }^{7,8}$. Only 3 studies collected seroprevalence data from young children after the introduction of universal childhood vaccination $^{8-10}$. Aside from children less than two years old in those studies, all the measures of seropositivity in this review are indicators of naturally-acquired infection.

Quality assessment. After removing duplicate entries that appeared in more than one database, 118 journal articles and 7 conference

Table I. Grading Scale For Quality Assessment of the Studies ${ }^{21}$.

\begin{tabular}{lcc}
\hline Sampling method & Geographic scope & Grade \\
\hline & Nation / multiple regions & A \\
Population-based random sample & Region / large city & B \\
& Small town & C \\
Convenience sample from a healthy source population & Nation / multiple regions & B \\
(such as workers, students, or healthy blood donors) & Region / large city & C \\
& Small town / one hospital & D \\
Convenience sample from inpatients or outpatients & Nation / multiple regions & B \\
& Region / large city & C \\
& Small town / one hospital & D \\
\hline
\end{tabular}




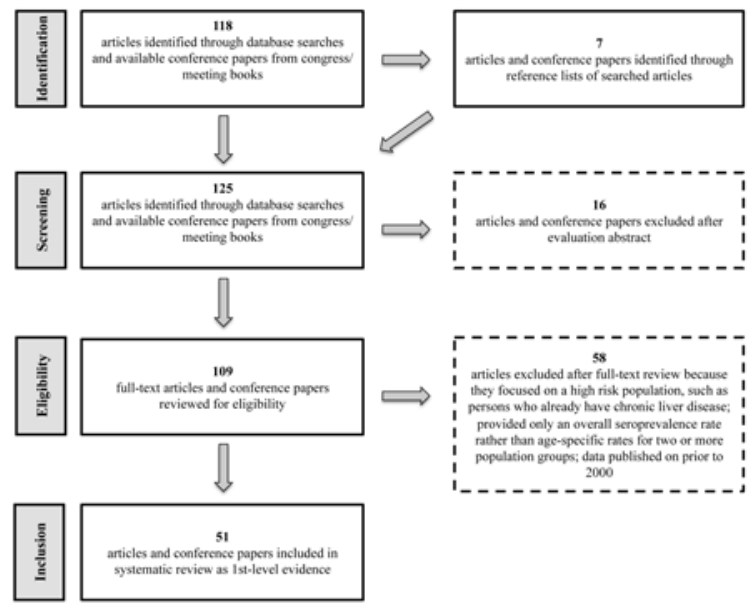

Fig. 1. Flowchart for the systematic review.

abstracts were examined for eligibility. Sixteen studies were excluded after abstract review. Fifty-eight additional articles were excluded after a full-text review because they did not meet all of the eligibility criteria. In total, 51 studies were included in the final analysis (Fig. 1). For each study, critical information about the study site, study design, data collection years, sampling method, sample size, study population, and age-seroprevalence rates was extracted. All of the studies were then graded based on their sampling methods and the representativeness of the study population, as per the method proposed by Itani et al. ${ }^{11}$ in a previous paper about hepatitis $\mathrm{A}$ in the Middle East region (Table I).

Endemicity assignment. The age at midpoint of population immunity to HAV is the youngest age at which at least half of the population has serologic evidence of prior infection with $\mathrm{HAV}$, and this is a recommended indicator of HAV endemicity status ${ }^{1,5,11}$. To find the age at midpoint of population immunity for each included study, the midpoint of each age group in a study population was plotted on the $\mathrm{x}$-axis and the corresponding seroprevalence rate on the y-axis. GraphPad Prism (version 6.0, GraphPad Software, Inc., La Jolla, CA, USA) was used to fit various types of curves to the data points. The best-fit curve from among different logarithmic, polynomial, and sigmoidal curves was the one with the $r^{2}$ value nearest to 1 . The equation for the best-fit curve was used to calculate the age at which seroprevalence was first equal to $50 \%$. Endemicity rates were assigned to each study based on the ages at midpoint of population immunity and the categories presented in previous HAV reports: very high for less than 5 years, high for 5 to 14 years, intermediate for 15 to 34 years; and low for 35 years and older 5,11 . When the endemicity levels for each province were mapped, endemicity was assigned based on a consideration of the studies with the highest quality grades, the largest sample sizes, and the most recent data. We also used graphing methods to identify the seroprevalence rate at the midpoint of four age groups: ages birth to 10 years, 11 to 20 years, 21 to 50 years, and 51 years or older.

Socioeconomic indicators. Four province-level indicators were used to evaluate possible associations between socioeconomic development and hepatitis A endemicity. Data about the proportion of the population whose drinking water comes from a municipal water system and is regularly inspected by the Ministry of Health and about access to sewage systems were acquired from the Turkish Statistical Institute affiliated to the Ministry of Development ${ }^{12,13}$ because access to water is known to be a risk factor for $\mathrm{HAV}^{2,3}$. Data about the percentage of each province living in cities was also collected along with the province development index (PDI), which is a composite of 60 different sociodemographic, health, education, employment, urbanization, infrastructural, financial, and equality indicators compiled and ranked by the Ministry of Development ${ }^{14,15}$. Each province is assigned a PDI between 1 (for high levels of development) and 6 (for low levels of development). Various descriptive statistics, comparative tests, and correlations were used to examine relationships between these socioeconomic indicators and various HAV metrics. All statistics were calculated with SPSS version 22 with a significance level of $\mathrm{p}<0.05$.

\section{Results}

Using the methods describe above, an endemicity level and age-specific HAV seroprevalence could be assigned to 23 of the 81 provinces in Turkey based on the studies included in the systematic review and meta-analysis. This included 8 of 19 provinces in the western region (Table II), 7 of 


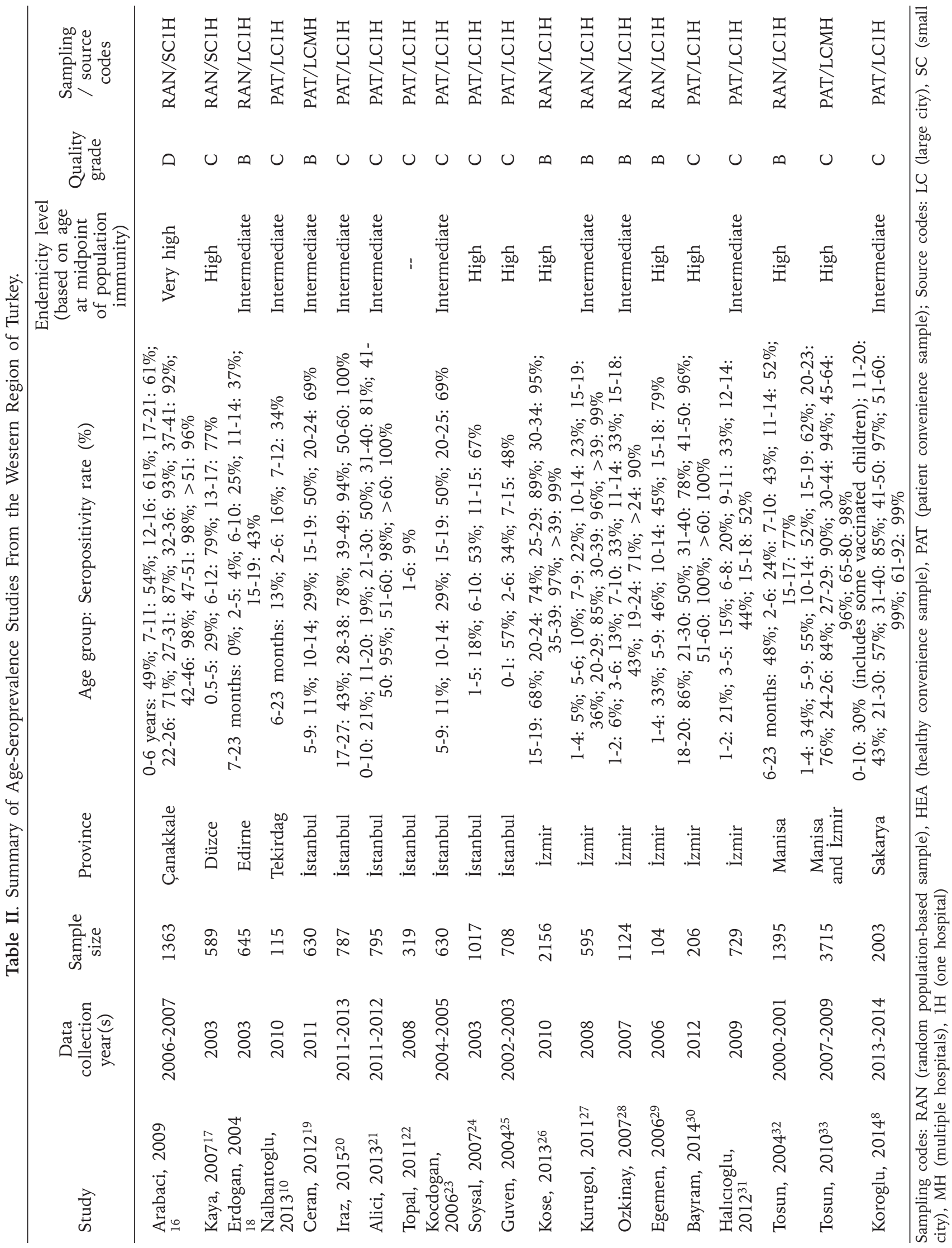




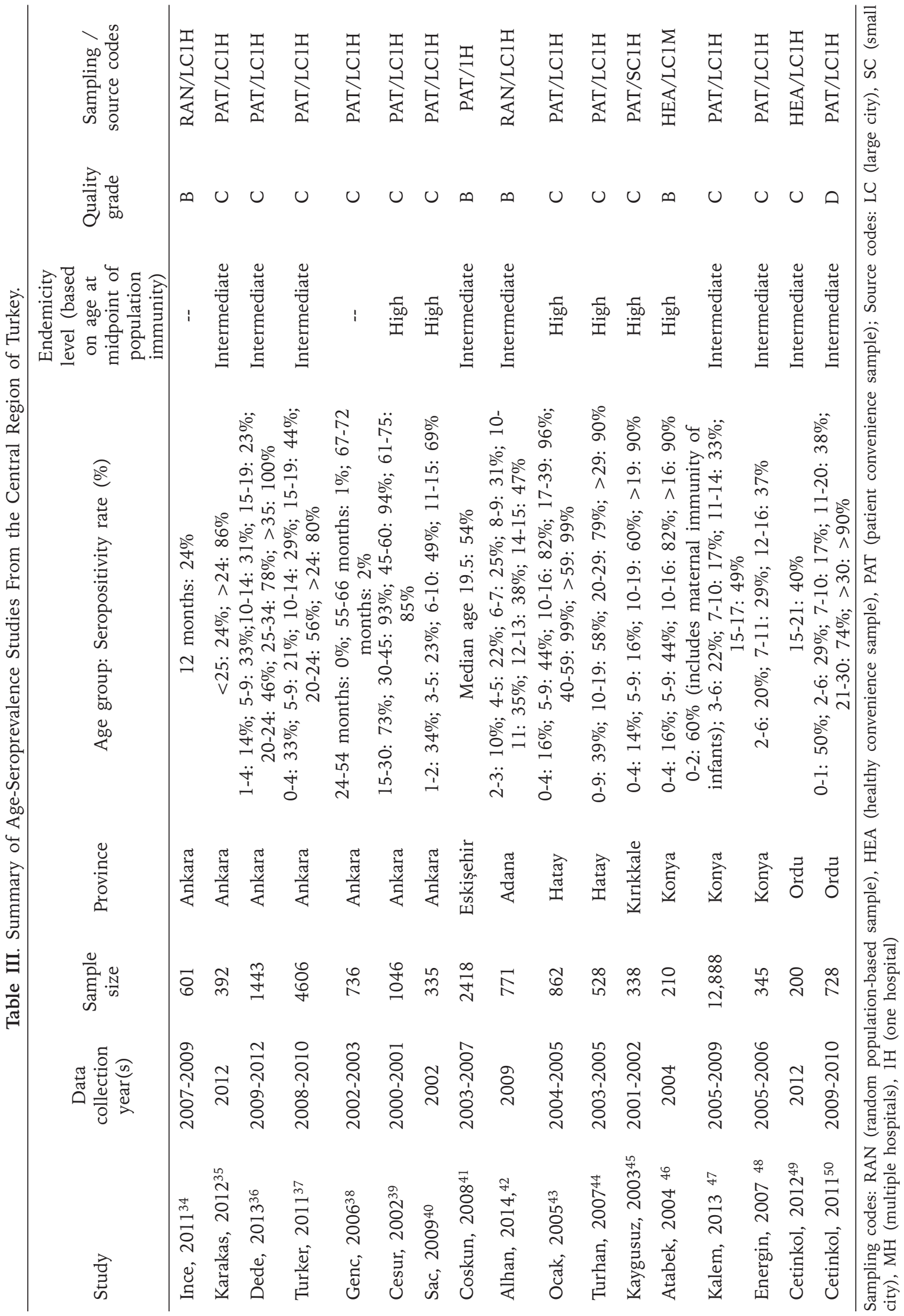


out 32 provinces in the central region (Table III), and 8 of 30 provinces in the eastern region (Table IV). For the remaining 58 provinces, no available data met the inclusion criteria.

A map of PDIs shows a substantial development gradient in Turkey, with the western region the most developed area and the eastern region much less developed (Fig. 2). By contrast, a map of HAV endemicity does not reveal such a clear trend (Fig. 3). Each region has a mix of provinces intermediate, high, and very high endemicity level (Table V). Access to water and sanitation are not significantly associated with endemicity, and urbanization and PDI are also not strong predictors. Perhaps the most notable trend is that urban areas like Istanbul (the largest metropolitan area), Ankara (the nation's capital and the $2^{\text {nd }}$ largest city), and Izmir (the $3^{\text {rd }}$ largest city) tend to have lower rates than studies from more rural areas. Provinces with a more urban population tended to have intermediate endemicity and provinces with a more rural population tended to have high endemicity. This prediction does not süit the provinces where it has migration areas and underdeveloped neighborhoods since such areas cause artificial increase in endemicity. ${ }^{27}$

However, a consideration of the quality of the evidentiary base for categorizations support an endemicity pattern more in line with the PDI scores. In the western and central regions, the recent studies almost uniformly indicate an intermediate endemicity while older studies report seroprevalence rates consistent with high endemicity. Importantly, the seroprevalence rates in children ages $0-10$ years are different in the three regions even though the adults' rates are not significantly different (Fig. 4). This suggests that the incidence rate has decreased in the western and central regions over the past 15 years, and these areas have transitioned from high to intermediate endemicity patterns. In the eastern region, a mix of intermediate, high, and very high endemicity levels is reported, and recent studies cover this range of epidemiological profiles. As a result, this data indicates that the incidence rate remains higher in this part of the country than it is in Turkey's other regions.

\section{Discussion}

The 23 provinces able to be assigned a hepatitis A endemicity level based on this systematic review and analysis of data from the past 15 years are home to 42.3 million of Turkey's 77.6 million residents, or about $55 \%$ of the total population ${ }^{64}$. The results of this analysis show that it would be an oversimplification to classify Turkey as a country with intermediate endemicity without acknowledging the heterogeneity of different regions within Turkey. However, they also reveal some general trends. The incidence rates for symptomatic hepatitis A infection are higher in the eastern part of Turkey than in the western and central region ${ }^{65}$, and this is reflected in the differences in child seropositivity by region in this analysis.

These disparities and the variations in socioeconomic indicators by region both support the likelihood of lower seroprevalence rates in the western parts of the country and higher rates in the eastern region. Similar within-country differences in hepatitis A profiles have been observed in other countries. For example, rates are higher in northern than southern Brazil66, they are higher in southern than northern Mexico ${ }^{67}$ and they are higher in southern than northern Italy68. There are also notable differences in the hepatitis A endemicity profiles between urban and rural areas of Turkey. However, even some higherincome areas had hepatitis A profiles suggesting high rather than intermediate endemicity. Internal and external migration may explain some of those observations especially for cities such as Izmir and Canakkale. Additional studies from across Turkey-ones that use population-based samples with sufficiently large numbers of participants from a range of age groups, including children-are needed to confirm the current heterogeneity of hepatitis A seroprevalence and the drivers of those profiles.

HAV endemicity is an indicator of both current and past hepatitis A incidence rates. An age at midpoint of population immunity in children who are not yet of school age-a "very high" endemicity-means that the majority of very young children in a population have been exposed to the virus early in their lives. Places categorized as having very high endemicity in this study can be assumed to have a high current HAV incidence rate. By contrast, an age at midpoint of population immunity in 


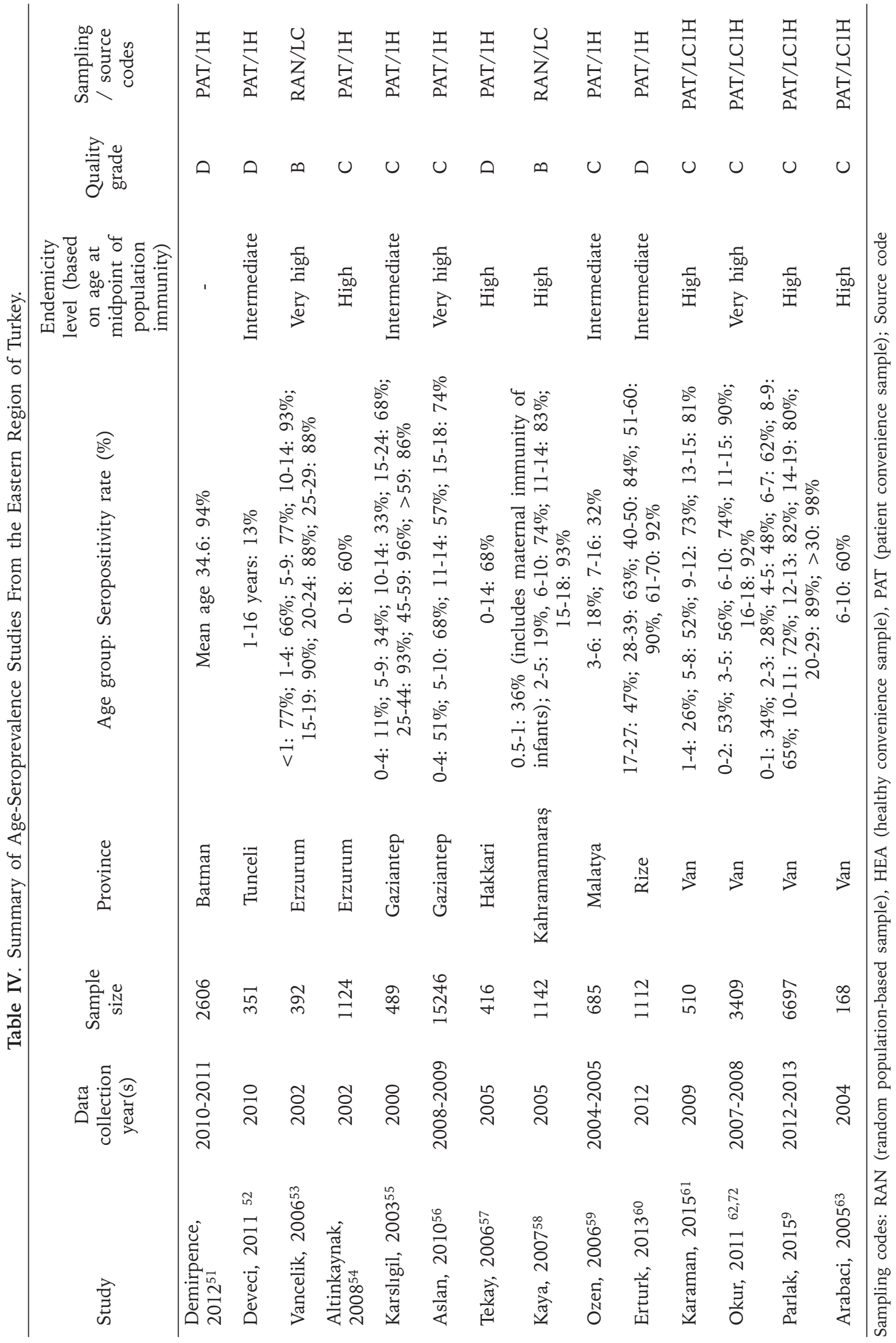




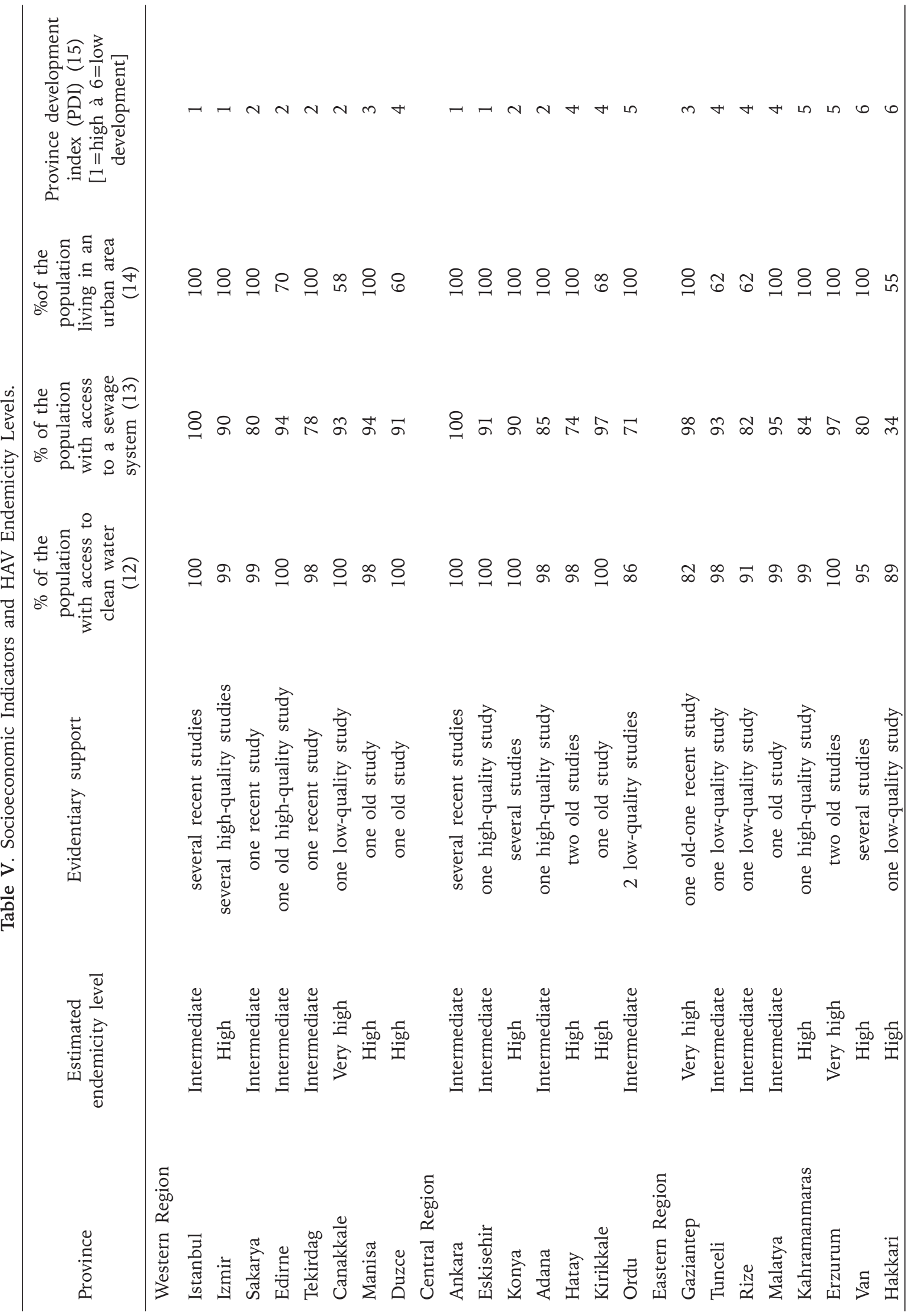




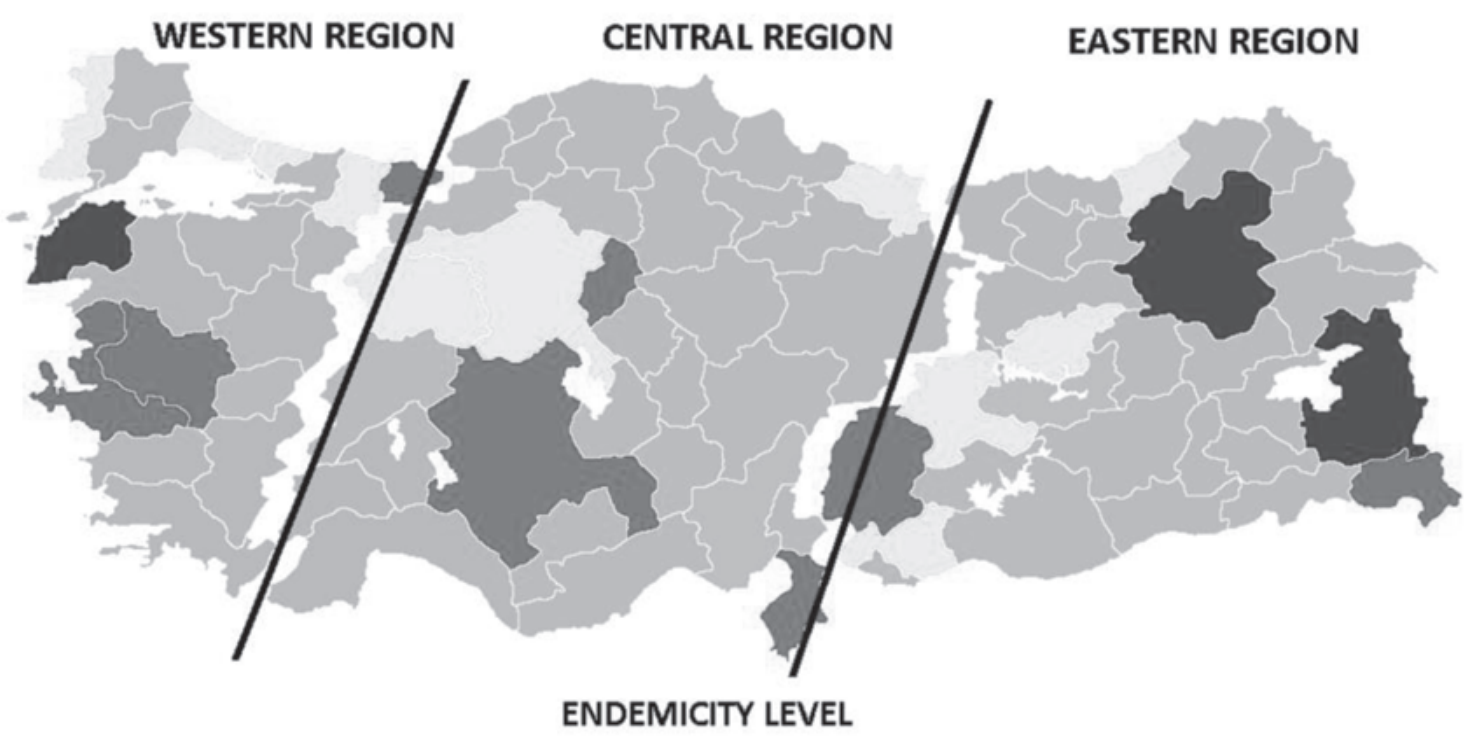

O INTERMEDIATE O HIGH O VERY HIGH

Fig. 2. Map of province development index (PDI) levels across Turkey.

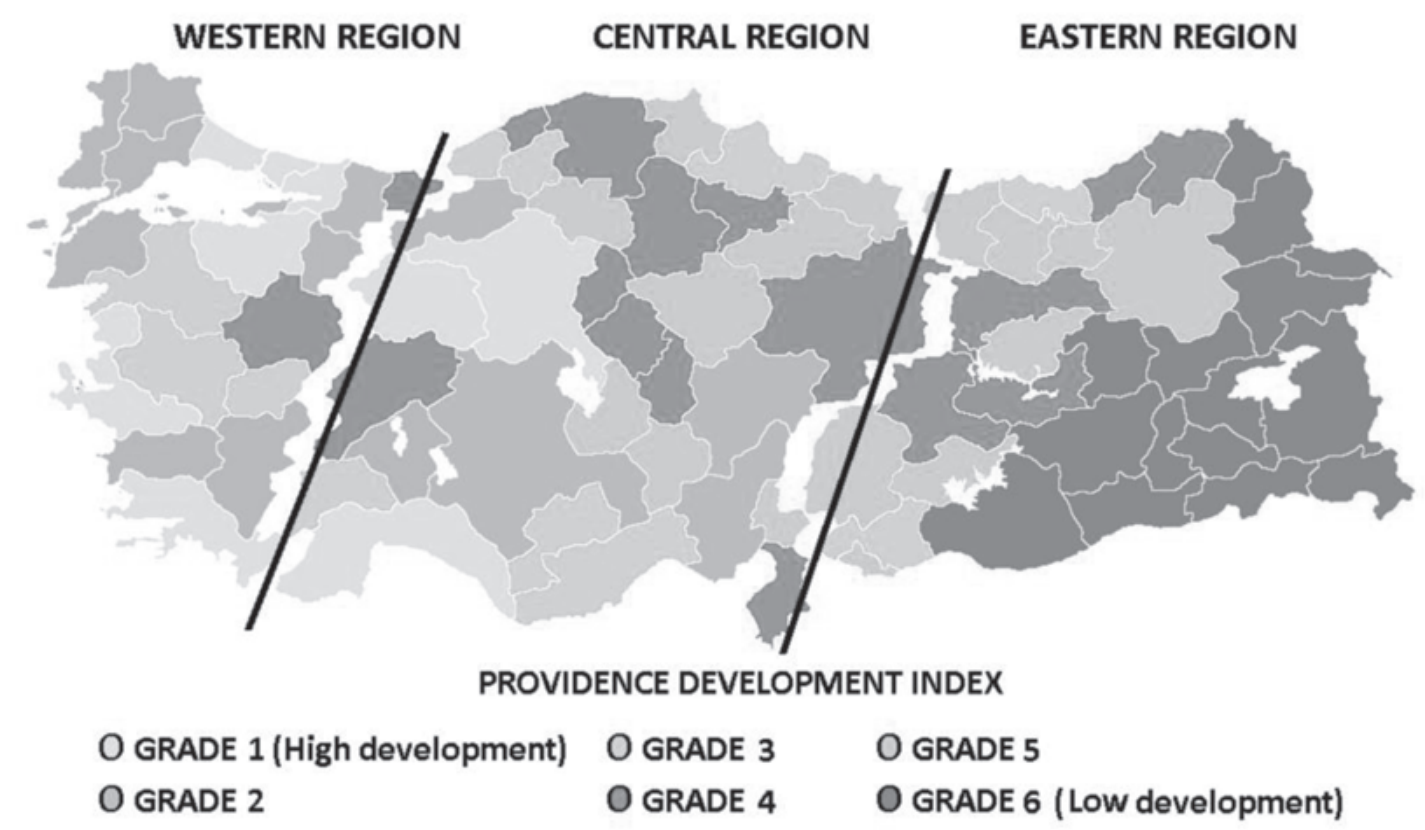

Fig. 3. Map of estimated hepatitis A endemicity levels by province in Turkey, based on the current review.

adolescence or early adulthood-which in this study was classified as an "intermediate" endemicity-requires the HAV incidence rate to have been relatively low for at least 15 years because more than half of teenagers have avoided exposure to the virus during their lifetimes. This review suggests that hepatitis A incidence rates in Turkey have declined over the past 15 years, and that this decrease is continuing even in urban areas that already have intermediate endemicity but may be moving toward low endemicity. This epidemiological 


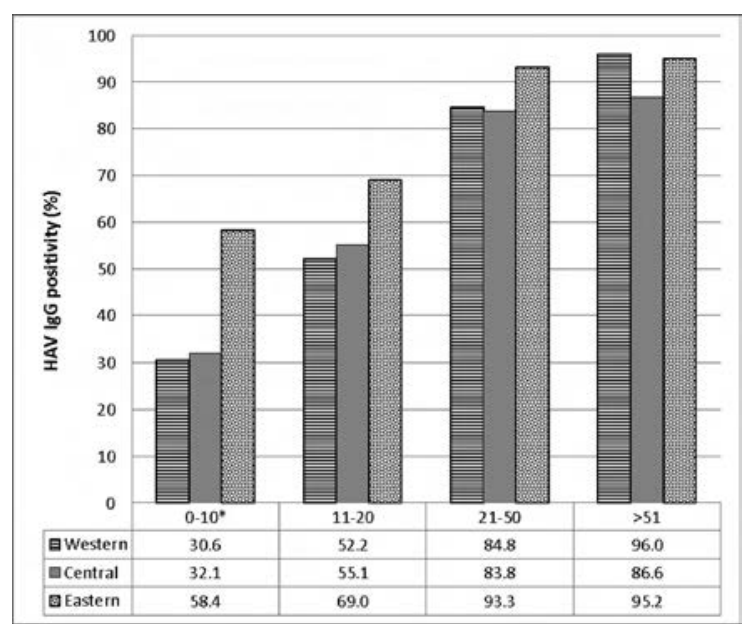

Fig. 4. Estimated anti-HAV IgG seroprevalence rates by age group and region of Turkey.

transition is supported by incidence data from the Ministry of Health. The number of reported cases of acute hepatitis A infection (which will have captured only a small percentage of all cases, since young children with hepatitis A are unlikely to be symptomatic) was 24,772 in 1995 then decreased to 10,654 in 2000,9229 in 2005, 2787 in 2010, and 3894 in $2011^{69}$. The uptick in cases from 2010 to 2011 was attributed to an outbreak among asylum-seekers from Syria who had settled in the border city of Hatay ${ }^{69}$. New population-based seroprevalence studies in Turkey will need to differentiate between long-term residents and those who have migrated from other parts of Turkey or who have immigrated to Turkey from nearby countries such as Syria that have higher rates of hepatitis A due to current and/or historic conflicts that have disrupted public health ${ }^{11}$.

Future seroprevalence studies involving participants born after the introduction of hepatitis A vaccine as part of the routine childhood immunization schedule in Turkey in 2012 will also have to account for the possibility that the seropositivity rate in those age cohorts reflects vaccination status rather than natural infection. Universal childhood vaccination is recommended for places with intermediate endemicity, while targeted vaccination is considered most appropriate in places with low endemicity ${ }^{4,70}$. Based on those guidelines, Turkey's current policy of recommending hepatitis A immunization for all children without contraindications ${ }^{3,4}$ is an appropriate one and is likely to remain the best option for at least the next decade or two. The incidence rate will likely further decrease as a function of both the vaccination program and ongoing infrastructural development. At the same time, it is likely that there will be new outbreaks associated with human migration and international trade. Some outbreaks may occur in refugee camps, as was observed in 201169; others may be associated with travel or foods that spark sustained local outbreaks among susceptible adults and unvaccinated children. A strengthened health surveillance system and nationwide serosurveys will be valuable for monitoring emerging threats to public health along with tracking rates of uptake of childhood vaccination.

\section{REFERENCES}

1. Jacobsen $\mathrm{KH}$, Wiersma ST. Hepatitis A virus seroprevalence by age and world region, 1990 and 2005. Vaccine 2010; 28: 6653-6657.

2. Jacobsen KH, Koopman JS. Declining hepatitis A seroprevalence: a global review and analysis. Epidemiol Infect 2004; 132: 1005-1022.

3. Jacobsen KH, Koopman JS. The effects of socioeconomic development on worldwide hepatitis A virus seroprevalence patterns. Int J Epidemiol 2005; 34: 600-609.

4. WHO position paper on hepatitis A vaccines, June 2012. Wkly Epidemiol Rec 2012; 87: 261-276.

5. Mohd Hanafiah K, Jacobsen KH, Wiersma ST Challenges to mapping the health risk of hepatitis A virus infection. Int J Health Geogr 2011; 10: 57.

6. Moher D, Shamseer L, Clarke M, et al. Preferred reporting items for systematic review and meta-analysis protocols (PRISMA-P) 2015 statement. Syst Rev 2015; 4: 1 .

7. Avci HH, Selcuk EB, Pehlivan E, Hulya E. Implementation of a new vaccine in Turkey: hepatitis A. Eurasian J Fam Med 2014; 3: 9-14.

8. Koroglu M, Demiray T, Terzi HA, Altindis M. Seroprevalence of hepatitis A among different age groups in Sakarya and review of the literature. Viral Hepat J 2014; 20: 110-114.

9. Parlak M, Guven A, Erdin BN, Bayram Y. Seroprevalence of hepatitis-A virus among child and adult age groups admitted to a training and research hospital. Viral Hepat J 2015; 21: 20-22.

10. Nalbantoglu B, Donma M, Ozdilek B, Karasu E, Nalbantoglu A. Shifting epidemiology of hepatitis A infection and vaccination status of children aged 6 months-12 years: time for mass vaccination. Iran J Pediatr 2013; 23: 276-280.

11. Itani T, Jacobsen KH, Nguyen T, Wiktor SZ. A new method for imputing country-level estimates of hepatitis A virus endemicity levels in the Eastern Mediterranean region. Vaccine 2014; 32: 6067-6074. 
12. Turkish Statistical Institute. Municipal Water Statistics Database [Belediye Su İstatistikleri Veritaban1] 2012. http://www.turkstat.gov.tr/PreTabloArama. do? metod $=$ search $\&$ araType $=v t$

13. Turkish Statistical Institute. Municipal Wastewater Statistics Database [Belediye Atıksu İstatistikleri Veritaban1] 2012. http://www.turkstat.gov.tr/ PreTabloArama.do? metod $=$ search\&araType $=v t$

14. Turkish Statistical Institute. Selected Regional Statistics [Seçilmiş Bölge İstatistikleri] 2013. Available from: http://www.tuik.gov.tr/ilGostergeleri/index.html.

15. Taskaya S, Sahin B, Demirkiran M, Balcik P. The Relationship between Human Resources for Health and Development Levels of Provinces. J of Econ, Finance and Account 2015; 2: 672-679.

16. Arabaci F, Oldacay M. The seroprevalance of hepatitis A in different age groups and hepatitis A incidence in acute hepatitis cases in the Canakkale province. $\mathrm{J}$ Pediatr Infect 2009; 3: 58-61.

17. Kaya AD, Ozturk CE, Yavuz T, Ozaydin C, Bahcebasi T. Changing patterns of hepatitis A and E sero-prevalences in children after the 1999 earthquakes in Duzce, Turkey. J Paediatr Child Health 2008; 44: 205-207.

18. Erdogan M, Otkun M, Tatman-Otkun M, Akata F, Ture M. The epidemiology of hepatitis A virus infection in children, in Edirne, Turkey. Eur J Epidemiol 2004; 19: 267-273.

19. Ceran N, Yuksel Kocdogan F, Mert D, et al. Hepatitis A seroprevalence in children and young adults in Istanbul, Turkey: seroprevalence change and associated factors. J Viral Hepat 2012; 19: 72-76.

20. Iraz M, Gultepe B, Doymaz MZ. Seroprevalance of hepatitis $\mathrm{A}$ in the adult age groups. Abant Med J 2015; 4: 54-58.

21. Alici O, Agalar C, Yazicilar HA. Hepatitis A seroprevalence in patients who admitted to training and research hospital in Istanbul. Viral Hepat J 2013; 19: 100-114.

22. Topal E, Hatipoglu N, Turel O, et al. Seroprevalence of hepatitis A and hepatitis A vaccination rate in preschool age in Istanbul urban. J Pediatr Infect 2011; 5: $12-15$

23. Kocdogan FY. Relationship of socio-economic factors with hepatitis A virus from different age groups in Istanbul [İstanbul'da Farklı Yaş Gruplarında Hepatit A Prevalansı ve Sosyo-Ekonomik Faktörlerle İlişkisi] [master's thesis]. Istanbul: Haydarpaşa Numune Education and Training Hospital; 2006.

24. Soysal A, Gokce I, Pehlivan T, Bakir M. Interchangeability of a hepatitis A vaccine second dose: Avaxim 80 following a first dose of Vaqta 25 or Havrix 720 in children in Turkey. Eur J Pediatr 2007; 166: 533-539.

25. Guven F, Erkum AY, Erkum T, Say A. Seroprevalence of hepatitis A in children age 0-15. Zeynep Kamil Tip Bulteni 2004; 35: 41-44.

26. Kose S, Mandiracioglu A, Cavdar G, et al. The seroprevalence of hepatitis A in adults in Izmir: prior to introducing vaccine into routine vaccination program. Nobel Med 2013; 9: 49-53.
27. Kurugol Z, Aslan A, Turkoglu E, Koturoglu G. Changing epidemiology of hepatitis A infection in Izmir, Turkey. Vaccine 2011; 29: 6259-6261.

28. Ozkinay F, Kurugol Z, Koturoglu G, et al. The epidemiology of hepatitis A infection in the population of Bornova, Izmir, Turkey. Ege Tip Dergisi 2007; 46: $1-6$.

29. Egemen A, Yilmaz O, Akil I, Altuglu I. Evaluation of association between hepatitis A and Helicobacter pylori infections and routes of transmission. Turk J Pediatr 2006; 48: 135-139.

30. Bayram ED, Ergin OY, Tosun S. Evaluation of the changes at the ages of contact with hepatitis A virus. Proceedings of the $12^{\text {th }}$ National Congress of Viral Hepatitis; Antalya, 2014: 114.

31. Halicioglu O, Akman SA, Tatar B, Atesli R, Kose S. Hepatitis A seroprevalence in children and adolescents aged 1-18 years among a low socioeconomic population in Izmir, Turkey. Travel Med Infect Dis 2012; 10: 4347.

32. Tosun S, Ertan P, Kasirga E, Atman U. Changes in seroprevalence of hepatitis A in children and adolescents in Manisa, Turkey. Pediatr Int 2004; 46 :669-672.

33. Tosun S, Ayaz H, Deveci S, Aksu S. Evaluation of the contact status of the children and adults with Hepatitis A virus. Proceedings of the $10^{\text {th }}$ National Congress of Viral Hepatitis; Antalya, 2010: 121.

34. Ince OT, Yalcin SS, Yurdakok K, Ozmert EN. Hepatitis A seroprevalence among infants aged 12 months in Ankara. Turk J Pediatr 2011; 53: 114-116.

35. Karakaş A, Coşkun O, Mert G, Gul Hanefi C, Avci IY, Eyigun CP. What has changed in Hepatitis A seroprevalence in seven years. Proceedings of the $12^{\text {th }}$ National Congress of Viral Hepatitis; Antalya, 2012: 51.

36. Dede A, Caliskan E, Guven GB, Cizmeci Z. Hepatitis A seropositivity in outpatients at Kecioren Teaching and Research Hospital Viral Hepat J 2013; 19: 163164.

37. Turker K, Balci E, Bati S, Hascuhadar M, Savas E. The changing epidemiology of hepatitis A infection in Turkey. Turk Mikrobiyol Cem Derg 2011; 41: 143-148.

38. Genc G, Yilmaz G, Karacan C, Atay N, Yoney A. Hepattis A seroprevalence among 2-6 year-old children of low socioeconomic class families. Erciyes Med J 2006; 28: 188-191.

39. Cesur S, Akin K, Dogaroglu İ, Birengel S, Balik İ. Hepatitis A and hepatitis E seroprevalence in adults of Ankara area. Mikrobiyol Bul 2002; 36: 79-83.

40. Sac R, Bostanc I, Dallar Y, Cihan G, Atli O. Hepatitis A seroprevalence and demographics in Turkish children in Ankara. Pediatr Int 2009; 51: 5-8.

41. Coskun O, Erdem H, Gul HC, Eyigun CP. Changes in hepatitis A prevalence rates between 1998 and 2007 in Eskisehir, Turkey. Int J Infect Dis 2008; 12: e141.

42. Alhan E, Kozanoglu B, Tumgor G, Celik U, Yaman A, Bozdemir N. Epidemiological shift of hepatitis A in central Adana, Turkey. Turk J Gastroenterol 2014; 25: S6-S8. 
43. Ocak S, Kaya H, Cetin M, Inandi T. Seropositivity of hepatitis A and B according to age and sex in preoperative patients in Antakya.Viral Hepat J 2005; 10: $169-175$.

44. Turhan E, Cetin M. The seroprevalence of viral hepatitis A in patients who had consulted at Mustafa Kemal University of Medicine Faculty. Viral Hepat J 2007; 12: 30-34.

45. Kaygusuz S, Kilic D, Ayaslioglu E, Ozluk O, Cerit L, Yildirim A. Seroprevalence of anti-HAV, HBsAg, anti-HBs and anti-HCV according to age and sex in Kirikkale. Viral Hepat J 2003; 8: 160-165.

46. Atabek ME, Findik D, Gulyuz A, Erkul I. Prevalence of anti-HAV and anti-HEV antibodies in Konya, Turkey. Health Policy 2004; 67: 265-269.

47. Kalem F, Erayman B, Yuksekkaya Ş, Kara F. The seroepidemiology of hepatitis A in Konya. Viral Hepat J 2013; 19: 19-22.

48. Energin VM, Elmas S, Sert A. Frequency of hepatitis B in children applying to outpatient clinics of pediatrics in Meram Medical Faculty of Selcuk University. Selcuk Tip Derg 2007; 23: 161-166.

49. Cetinkol Y, Yildirim AA. The evaluation of the HBsAg, anti-HBs, anti-HCV and anti-HAV IgG results in medical career college students. Viral Hepat J 2012; 18: 23-25.

50. Cetinkol Y, Altuncekic Yildirim A. The seroprevalence of viral hepatitis A in patients who had been consulted at Unye State Hospital. Kocatepe Med J 2011; 12 : 18-22.

51. Demirpence O, Tezcan SI, Degirmen E, Mert D, Gumuş A, Celen MK. Seroprevalence of HAV, HBV, HVC and HIV in people admitted to Batman State Hospital. Viral Hepat J 2012; 18: 6-10.

52. Deveci U, Ustun C, Hamanca O. Seroprevalence of hepatitis A virus among children aged 1-16 years in Eastern Anatolia, Turkey. Afr Journal Microbiol Res 2011; 5: 5969-5971.

53. Vancelik S, Guraksin A, Alp H. Hepatitis A seroepidemiology in Eastern Turkey. East Afr Med J 2006; 83: 86-90.

54. Altinkaynak S, Selimoglu MA, Ertekin V, Kilicaslan B. Epidemiological factors affecting hepatitis A seroprevalence in childhood in a developing country. Eurasian J Med 2008; 40: 25-28.

55. Karsligil T, Eksi F, Balci İ, Belgin R. The seroprevalence of hepatitis A and E in our region. Viral Hepat J 2003; 8: 155-159.

56. Aslan S, Degirmenci S, Citak C, Yis R. Evaluation of hepatitis A indicators in Gaziantep Children's Hospital in two years-period. Proceedings of the $10^{\text {th }}$ National Congress of Viral Hepatitis; Antalya, 2010: 117.

57. Tekay F. Hepatitis A frequency in children of between 0-14 age group who had consulted at Hakkari Province Hospital. Dicle Tip Dergisi 2006; 33: 245-247.
58. Kaya D, Guler E, Ekerbicer HC, et al. Hepatitis A seroprevalence and its relationship with environmental factors in children of different age groups in Kahramanmaras, Eastern Mediterranean region of Turkey. J Viral Hepat 2007; 14: 830-834.

59. Ozen M, Yologlu S, Isik Y, Tekerekoglu MS. Anti-HAV IgG seropositivity in children aged between 2-16 years who were admitted to Turgut Ozal Medical Center. Türk Pediatri Arşivi 2006; 41: 36-40.

60. Erturk A, Copur Cicek A, Cure E, Akdogan RA, Ozturk C. Seroprevalence of hepatitis A in Rize Province and different adult age groups. Viral Hepat J 2013; 19: 85-88.

61. Karaman S, Karaman K, Kizilyildiz BS, et al. Seroprevalence of hepatitis A and associated factors among 1-15 year old children in eastern Turkey. Int J Clin Exp Med 2015; 8: 19394-19399.

62. Okur M, Erbey F, Acar MN, Guven A, Kaya A. The seropositivity of hepatitis A in children between 0-18 years in the Van province and around. Duzce Med J 2011; 13: 6-9.

63. Arabaci F, Demirli H. The seroprevalence of hepatitis $A$ and $B$ in children 6-10 years of age Turk J Infect 2005; 19: 457-460.

64. Turkish Statistical Institute. Population of provinces by years, 2007-2014 [Yillara göre il nüfusları, 2007-2014] 2014. http://www.tuik.gov.tr/PreTablo.do?alt_id=1059

65. Ceyhan M, Yildirim I, Kurt N, et al. Differences in hepatitis A seroprevalence among geographical regions in Turkey: a need for regional vaccination recommendations. J Viral Hepat 2008; 15: S69-S72.

66. Ximenes RA, Martelli CM, Amaku M, et al. Modelling the force of infection for hepatitis $\mathrm{A}$ in an urban population-based survey: a comparison of transmission patterns in Brazilian macro-regions. PLos One 2014; 9: e94622.

67. Lazcano-Ponce E, Conde-Gonzalez C, Rojas R, DeAntonio R, Romano-Mazzotti L, Cervantes Y, Ortega-Barria E. Seroprevalence of hepatitis A virus in a cross-sectional study in Mexico: implications for hepatitis A vaccination. Hum Vaccin Immunother 2013; 9: $375-381$.

68. Ansaldi F, Bruzzone B, Rota MC, Bella A, Ciofi degli Atti M, Durando P, et al. Hepatitis A incidence and hospital-based seroprevalence in Italy: a nation-wide study. Eur J Epidemiol 2008; 23: 45-53.

69. Mistik R. Epidemiology of the hepatitis A virus infections [Hepatit A Virus Enfeksiyonunun Epidemiyolojisi]. In: Tabak F, Tosun S, editors. Viral Hepatitis [Viral Hepatit], $1^{\text {st }}$ ed. Istanbul: Istanbul Tip Kitabevi; 2013: 15-23.

70. Yoldas O, Bulut A, Altindis M. The Current Approach of Hepatitis A Infections. Viral Hepat J 2012; 18: 8186. 